\title{
The Empirical Evaluation of the Determinants of Industrial Manufacturing in the CEMAC Zone
}

\author{
Louis Bernard Tchekoumi ${ }^{1} \&$ Patrick Danel Nya ${ }^{1}$ \\ ${ }^{1}$ Laboratoire d'Economie Théorique et Appliquée (LETA), Faculty of Economics and Applied Management, \\ University of Douala, Cameroon \\ Correspondence: Louis Bernard Tchekoumi, Laboratoire d'Economie Théorique et Appliquée (LETA), Faculty of \\ Economics and Applied Management, University of Douala, Cameroon.
}

Received: May 30, 2019

doi:10.5430/rwe.v10n1p72
Accepted: June 23, 2019

Online Published: June 24, 2019

URL: https://doi.org/10.5430/rwe.v10n1p72

\begin{abstract}
The aim of this article is to assess the determinants of industrial manufacturing in the CEMAC zone. To achieve this, we make use of a gravity model on a static panel with random effects, according to the methodology proposed by Hausman-Taylor. The results show that the population, value added of the manufacturing sector, colonial links and geographic proximity have significant impacts with the expected signs. On the other hand, the difference in absolute value of per capita GDP, the business climate, financial inflows as well as actual distance are the group variables that arise as constraints to export manufacturing.
\end{abstract}

Keywords: gravity model, export, panel

JEL: L6, F14, C23, R12.

\section{Introduction}

A vast literature focus on industrialization in developing countries, these analyses have as starting point, the identification of their international integration. This permits the location and assessment of their overall integration. This approach, which has the disadvantage of the focus on external factors, translates the refusal to recognize these countries margin initiative, autonomy and flexibility in their own restructuring (Courlet, 1988). Yet, to accumulate economic and social dynamics which are being implemented in these countries. Indeed, on the basis of the main development strategies implemented, Ominami (1986) thinks that industrialization depends not only on the ability to substitute for imports, primary export promotion, but also on the substitution of exports which are based on the export of manufactured goods. However, the increasing competitive nature of markets contributes to the acceleration of technological change and specialization, which increases the uncertainty surrounding the investment decisions of companies (Hinitch et al., 1996; Van de Ven, 2005).

Companies must provide answers to the problems posed by the new market environment increasingly characterized by competition from intermediate goods (Rajan \& Zingales, 1998). That is why according to Norro (1998), industrial manufacturing in Africa is, possibly linked to production and farm incomes. Under this assumption, if earnings improve, demand for manufactured goods also increases. However, as nowadays the problem of industrial manufacturing arises in the context of disengagement of the State, rapid technological change and the internationalization of the economy, the opportunity to produce manufactured goods at an affordable price depends on several factors. Among them there are, traditional variables (income per capita, population, distance between major cities, ...), the variables of integration (the common language, the colonial links, geographic proximity, ...) then institutional variables (business climate , financial inflows, value added of manufacturing, ...)

For this purpose, the gravity model is an important evaluation tool. It describes a relationship between the volumes of trade between two countries in terms of the size and the distance between them. It is part of the number of methods designed to assess the determinants of trade under trade agreements. Not only it has a lot of success in the field of studies of bilateral trade (Luo, 2001), but also it appears as a highly robust relationship. Its success and its robustness is explained theoretically by the gradual integration of the contributions of the new theory of international trade: intra-industry analysis, general equilibrium model in perfect competition and products differential, competition monopoly model (Evenett \& Keller, 2002), on the one hand; and by the many empirical contributions and the quality of the results obtained from the other (Avom, 2005). If the gravity model has the advantage to explain a significant 
proportion of the variation in global trade (De Melo \& Grether, 1997), it may thereby assess exports and imports manufacturing as part of this work.

Initially the model of gravity States that the flow of competition between partner countries varies proportionally to the value of their income and inversely proportionally compared to the distance between them (Tinbergen, 1962; Linneman, 1966; Pöyhönen, 1963). To compensate for the lack of theoretical foundations in its pioneers, Zugravu (2009) says that it is more and more recognized since the works of Anderson (1979) the equations of gravity have varied theoretical foundations and its predictions may derive from different structural models. It's the models that include that of increasing returns to scale, and later Heckscher-Ohlin Ricardian (Bergstrand, 1985).

Therefore, the model of gravity recognizes renewals that allow regional dynamism adaptation and refinement of econometric techniques. Thus, it is favorable to take into account a number of explanatory variables that can be introduced according to the applications or the desired objectives (Laporte, 1998; Havrylyshyn \& Pritchett, 1991; Carrère, 2004; Gbetnkom \& Avom, 2005; Novy, 2012). Based on the problems of the study, variables taken into account, the space considered, and then data sources, this works has led to interesting results, some as others. What is the advantage of reflection based on such a model?

With almost inexistence of research work with particular scope to the CEMAC countries, our contribution is twofold. First, our work aims to fill the gap in the literature; as such, we intend to assess exclusively the determinants of industrial manufacturing between 2004 and 2014. Then, the equation of gravity model that we have formulated for the evaluation will enable us to locate the manufacturing industries in CEMAC and to see what could be their specificities.

The rest of the paper is organized as follows: section 2 presents the methodology. In section 3, the results are presented and discussed. Section 4 is the conclusion.

\section{Research Methodology}

In this section, the specification of the Gravity Model is first explained before outlining the data and their sources. The estimation strategy adopted is also presented.

\subsection{Specification of the Gravity Model}

Through the approach of Deardorff (1998), Baier and Bergstrand (2001), Anderson and Van Wincoop (2003), Anderson and Yotov (2010), and of the possible adaptations from the simple gravity model, we will progressively specify the model that would enable the assessment of the determinants of industrial manufacturing. In this logic, the original model is as follows:

$$
X M_{i j}=A \cdot \frac{Y_{i}^{a_{1}} Y_{j}^{a_{2}}}{D_{i j}^{a_{3}}}
$$

According to equation (1), the volume of the bilateral trade between two countries $\mathrm{i}$ and $\mathrm{j}$ measured by exports or imports (here exports manufacturing $\left.\left(E M_{i j}\right)\right)$ is explained by the products of the respective GDPs of country i

$\left(Y_{i}\right)$ and country $\mathrm{j}\left(Y_{j}\right)$ and the distance $\left(D_{i j}\right)$ between them; A is a constant.

To be able to interpret the coefficients of each variable in terms of elasticity, equation (1) shall be put in the logarithmic form following the method of Rose (2000). Thus:

$$
\log \left(E M_{i j}\right)=\log (A)+a_{1} \log \left(Y_{i}\right)+a_{2} \log \left(Y_{j}\right)+a_{3} \log \left(D_{i j}\right)
$$

Although this model is remarkable, it remains however that exports manufacturing are not only influenced by the two factors of GDP and distance. Other characteristics relating to country i or country $j$ also count. They contribute to improve and expand the scope of the initial model, while limiting the risk of bias in the estimates of the coefficients which may arise from the omission of relevant variables. Moreover, the addition of variables enable us better capture the effect of the other features of business partners (Luo, 2001).

Our work focuses on the performance of exports manufacturing. To this end, our choice was based on non gravitational variables applied in the various CEMAC countries. Structured in three methodical arrangements. We 
have those which are quantitative and vary with time; those related to a country, or that bind to two countries. Then there are those, which register in the rank of the dummy variables.

Whereas the difference in the level of economic development among the CEMAC countries is relatively important, according to Heckscher-Ohlin theorem, it is assumed that these countries intensive trade manufacturing is based on factors different in view of their comparative advantages due to their endowment factors. In this sense, the population $\left(P O_{i t}\right)$ variable has an impact on trade. It would then appear as a significant variable in the business opportunities between partner countries in the Exchange.

Several studies which have applied the gravity model using the distance through the air. Yet, the geodetic factors are vitally important in this area. That is why the actual distance $\left(C T_{i j}\right)$ best represents the actual transportation cost. It has the advantage of taking into account the unit cost of the road or the rail transport.

As more and more intra-regional trade grows and the CEMAC countries encourage through attractive policies, the diaspora and foreign investors, we believe that the external financial contributions $\left(A F E_{i}\right)$ (Note 1) play on exports. To better study the characteristic of intra-area trade, we retain the AFE to capture the effect of individual investors on exports manufacturing. The delayed variable of one year would be taken into account.

The industry manufacturing business climate indicator $\left(I C A_{i t}\right)$ measures the business climate as perceived by entrepreneurs in country i. Its value ranges from 0 to 10 . A high value, i.e. close to 10 means a favorable judgment of the entrepreneurs. This indicator offers an early signal on economic activity in manufacturing, since it is updated with the new information available.

The value added of a country's value added $\left(V A M_{i t}\right)$ corresponds to the value of revenues arising from the manufactured goods, taking into account the variation of inventories of goods in progress and finished products, but the cost of materials and supplies used, and the total cost of energy, water and fuel for car as well as amounts paid for contract work. The interest of the VAM is that it allows us to measure the net output of a sector after adding all outwards and subtracted from the inwards.

Three dummy variables are included, among which, language. It refers to the sharing of a common language $\left(L C_{i j}\right)$ between countries i and $\mathrm{j}$. It is the dummy that takes the value 1 when two trading partners' countries speak the same language and 0 otherwise. The colonial origin $\left(C L_{i j}\right)$ variable seems to have no importance in CEMAC. Yet taking this into account relate to the fact that all countries in this region did not have the same colonizer, which can justify their orientations, creations or trade diversions. $C L_{i j}$ takes the value 1 if the partner countries have the same colonizers and 0 if the colonizers are different. The proximity factor $\left(P G_{i j}\right)$ takes the value 1 when partners share a common border and 0 otherwise. 
Finally $\varepsilon_{i j t}$ represents the omitted explanatory variables, the orthogonal explanatory variables that express a random presentation. By introducing all these variables into a model specified in the data panel, the economic model appears as below:

$$
\begin{aligned}
& \log \left(E M_{i j}\right)=\log A+a_{1} \log \left(y_{i}\right)+a_{2} \log \left(y_{j}\right)+a_{3} \log \left(P O_{i t}\right)+a_{4} \log \left(C T_{i t}\right) \\
& +a_{5} \log \left(A F E_{i(t-1)}\right)+a_{6} \log \left(I C A_{i t}\right)+a_{7} \log \left(V A M_{i t}\right)+a_{8} \log \left(L C_{i j}\right)+a_{9} \log \left(C L_{i j}\right) \\
& +a_{10} \log \left(P G_{i j}\right)+\varepsilon_{i j t}
\end{aligned}
$$

In this model (3), the theoretical signs are the following:

$$
a_{1} \succ 0, a_{2} \succ 0, a_{3} \prec 0, a_{4} \prec 0, a_{5} \succ 0, a_{6} \succ 0, a_{7} \succ 0, a_{8} \succ 0, a_{9} \succ 0, a_{10} \succ 0 .
$$

\subsection{Data Sources}

The data used in this work are mostly from the online database of the World Development Indicators (WDI) of 2016 of the World Bank. The advantage of this source is that it is available and regular for all the countries of the world and especially to those of CEMAC. The study period is from 2004 to 2014. This period is conditioned by the availability of data. Extracted from this source:

- the per capita GDP of the country i (or j) at time t, Dollar (\$) USA;

- the total population $\left(\mathrm{PO}_{\mathrm{i}(\mathrm{j}) \mathrm{t}}\right)$ of country $\mathrm{i}(\mathrm{j})$ at time $\mathrm{t}$;

- $\quad$ exports Manufacturing $\left(\mathrm{EM}_{\mathrm{i}(\mathrm{j}) \mathrm{t}}\right)$ of country $\mathrm{i}$ to country $\mathrm{j}$ at time $\mathrm{t}$;

- manufacturing value added $\left(\mathrm{VAM}_{\mathrm{i}(\mathrm{j}) \mathrm{t}}\right)$ which is a consequence of manufacturing at the time exports $\mathrm{t}$;

- external financial flows $\left(\mathrm{AFE}_{\mathrm{i}(\mathrm{j}) t}\right)$ resulting from a share of private contributions consist of transfers of migrants, foreign direct investment and portfolio investment; then on the other hand, private contributions which consist of public aid for development.

- The real distances $\left(\mathrm{CT}_{\mathrm{ij}}\right)$ is taken from the website www.indo.com/distance/dist-formats.html. The distance is measured in kilometers between the main cities of the country $i$ and $j$. In general, these are political capitals which are taken into account. However, insofar as the political capital is not important, it is possible to take into account the economic capital of the country.

- For the indicators of business climate $\left(\mathrm{ICA}_{\mathrm{i}(\mathrm{j}) \mathrm{t}}\right)$, we take into account those of Doing Business which are available and are common to all the countries of the CEMAC that constitute the 13 variables

- The common language, the colonial links and geographic proximity are the dummies variables. They take the values 0 or 1. Apart from Equatorial Guinea where the language is Spanish, in the other five countries of the study area, French is spoken language. Also, compared to the colonial links, only Equatorial Guinea was colonized by Spain, others by France. The relative geographical proximities bring about the sharing of the land borders.

\subsection{Procedure for Estimating Econometric Models}

Without an interest in the composition of the random variable, a method for estimating simple model (3) perhaps the ordinary least square (MCO). It is easy to apply to the stacked data. Assuming that the temporal components of the disturbance are ongoing effects and not random, the model can also be estimated. In this case, the disturbances contribute to change the value of the intercept of the equation. Such an estimate can be optimal if more disturbances are intercepted; it satisfies the assumptions of the MCO which does not, however, exclude the possibility to use the random effect model, which insinuates that the components of the residue are random. It's obvious that the estimation technique is related to the assumptions taken into account and relative to the composition of the hazard. For this purpose, another possibility of estimating model (3) is the instrumental variables of Hausman and Taylor (1981). This method considers the endogeneity and the constancy of some variables. However, this method poses a number of problems, relating to the particular choice, the number and the validity of the instruments. In the light of the weaknesses related to these two estimation methods, in this work we choose the Panel data estimation. This method very often introduces a specific country couple's effect, in order to take into account characteristics which are not 
observable. We model then the couples effects like random variables because the estimate of the fixed effects model brings about the disappearance of the explanatory variables that do not vary in time.

\section{Results}

The results are presented in two subsections. The first is the descriptive statistics, followed by the presentation and interpretation of the results of estimation.

\subsection{Descriptive Statistics}

Table 1 provides summary statistics describing the analytic sample population. For the sample as a whole, the average manufacturing export is 0.9939 . The best export strategy is for the Central African Republic, which has the highest exports, which stands at 1.6820, compared to 0.4085 for Gabon, which has the lowest value of exports. Cameroon has the highest population indicator at 7.3465; while Equatorial Guinea offers the lowest value, which is 5.7684. With regard to external financial flows, with a value of 9.7135; Congo is the country that has benefited the most, while for the Central African Republic, this value, which is the lowest of the countries in the sample, is at 7.0317. For all CEMAC countries, while Cameroon has the largest manufacturing value added which is 9.5429 , Equatorial Guinea has the best indicator of the business climate of 0.845 . Moreover, the common language, colonial links and geographical proximity variables are all quite low for all the countries in which they take the value zero, except for Cameroon, for which they take the value one. This reflects similarities between the countries considered.

Table 1. Descriptive statistics

\begin{tabular}{lccccccc}
\hline Variables & Means & Std. Dev & Min & Max & Between & Within & Observations \\
\hline $\log$ EM & 0.9939 & 0.3888 & 0.408 & 1.682 & 0.2464 & 0.3350 & 66 \\
$\log \mathrm{Y}$ & 3.2516 & 0.5679 & 2.359 & 4.201 & 0.6155 & 0.0447 & 66 \\
$\log$ PO & 6.5928 & 0.4964 & 5.768 & 7.346 & 0.5381 & 0.0373 & 66 \\
$\log$ VAM & 8.5457 & 0.5990 & 7.189 & 9.542 & 0.8345 & 0.0669 & 66 \\
$\log$ AFE & 8.8887 & 0.4521 & 7.343 & 9.713 & 0.2992 & 0.3577 & 66 \\
$\operatorname{logICA}$ & 0.7903 & 0.0260 & 0.778 & 0.845 & 0.0000 & 0.0260 & 66 \\
$\log$ CT & 2.9783 & 0.0936 & 2.863 & 3.108 & 0.1017 & 0.0000 & 66 \\
CL & 0.8333 & 0.3755 & 0.000 & 1.000 & 0.4082 & 0.0000 & 66 \\
PG & 0.1666 & 0.3755 & 0.000 & 1.000 & 0.4082 & 0.0000 & 66 \\
LC & 0.8333 & 0.3755 & 0.000 & 1.000 & 0.4082 & 0.0000 & 66 \\
\hline
\end{tabular}

Source: authors.

\subsection{Presentation and Interpretation of the Results of Estimation}

Our estimates consider several stages. After considering the descriptive statistics, we find that we are in the presence of a static panel, i.e. the time effect is constant and so the individual effects are taken into account. Subsequently we estimated the fixed effect model and random effect and after the Hausman test, it is clear that the random effect model that is adopted. The model is generally robust with a value of 0.9998 between. The results of estimation are presented in the table below:

Table 2. Summary of the results

\begin{tabular}{ll}
\hline Independent Variables & $\log \mathrm{EM}$ \\
\hline $\log \mathrm{Y}$ & $-0.994^{* * *}$ \\
& $(0.243)$ \\
\hline $\log \mathrm{PO}$ & $-2.648^{* *}$ \\
& $(1.090)$ \\
\hline $\log \mathrm{VAM}$ & $0.811^{* * *}$ \\
& $(0.189)$ \\
\hline
\end{tabular}




\begin{tabular}{ll}
\hline $\log$ ICA & -3.193 \\
& $(2.229)$ \\
\hline $\log$ AFE & $-0.302 * *$ \\
& $(0.139)$ \\
\hline $\log$ CT & $9.901 * * *$ \\
& $(3.165)$ \\
\hline $\mathrm{CL}$ & $1.073 * * *$ \\
& $(0.282)$ \\
\hline PG & $2.603 *$ \\
& $(1.459)$ \\
\hline Constant & $-11.21 * *$ \\
& $(5.064)$ \\
\hline Observations & 66 \\
\hline Between & 0,9998 \\
\hline Hausman test EF vs EA & 0,7720 \\
\hline Signifiance $: * * * \mathrm{p}<0.01, * * \mathrm{p}<0.05, * \mathrm{p}<0.1$ & Margin type in bracket \\
\hline
\end{tabular}

Source: authors.

From the results, it is established that the volume of exports manufacturing between two countries of the CEMAC is a decreasing function of the difference in absolute value between the per capita GDP of these countries. The negative sign of GDP per head assumes the existence of a threshold effect (Bensafta, 2014). This result suggests that the positive transmission of GDP per head towards exports manufacturing is above a threshold below which the impact is negative.

Exports manufacturing country $\mathrm{i}$ to country $\mathrm{j}$ decline with population. The elasticity of the bilateral trade between these two countries is greater than unity in absolute value (-2.648). It is negative, reflecting a paradoxical effect whereby the small size of the population play negatively on exports manufacturing. A conclusion made by WTO (2002), the size of an economy may limit its ability to export products for which there are significant economies of scale. It is a constraint that prevents small economies to diversify their exports (Ocampo, 2005).

Regarding the value added manufacturing, the result shows a sign expected according to the empirical literature. Thus, it contributes positively and significantly to $1 \%$ to bilateral exchange. Indeed, the increase in value added manufacturing induces additional exports manufacturing. These additional exports highlight symmetrical drop to those of industrialized countries, and support the structural changes taking place in the CEMAC (Szirmai, 2012).

As for the indicators of the business climate, the result is mixed. The business climate refers to the institutional business environment in a given country. The perception of the business by the investor climate determines its decisions to invest or not. Indeed, the country that shows a good level of the business climate indicator is considered to be attractive in terms of investment, and providing a framework conducive to the development of the industry, for the redistribution of income. In this context, the negative result could be explained by the informal nature of the private sector, with the predominance of underemployment leading manufacturing companies to not prepare reports (United Nations, 2014).

The external financial flow variable has a contrary to the expected sign. Although it is significant, it is negative. This reinforces the idea that it occurred a change in the international financing for development. In the case of CEMAC, these contributions are less connected, less affected, less carriers of knowledge and more expensive (Guillaumont, 1978). So, the uptrend in the privatization of the international financing and the relative less direct investment then assistance contribute to justify the negative impact of external financial resources on exports manufacturing.

In the context of CEMAC, the actual distance is slight. It has a low character weight of which is in terms of exports manufacturing. Its sign is positive and significant. Theoretically we should expect a contrary result as that obtained by Agbodji (2007). A cautious interpretation of this result can be linked to the region reduced across the CEMAC 
countries. Which further strengthens the idea of making a genuine area of free movement of men and goods, supported the reduction of income inequality.

The dummy variables provide anticipated and significant coefficients $1 \%$, except the language variable. That's why it disappears from the summary table of results. It probably tends to degrade the exchanges between the countries of the CEMAC. This result is confirmed by Avom and Mignamissi (2013). For them, in addition to the languages spoken in CEMAC, that is, the French, English, Spanish and Arabic, if we add the national and those languages other partners in trade, the common language variable cannot that deteriorate the bilateral exchange. Conversely, having colonial links, like having common borders appear to favor export, whether it is a formal exchange or informal.

\section{Conclusion}

This article has permitted us to apply the gravity model in order to assess the determinants of industrial manufacturing in the CEMAC zone. The results do not always match those planned. It could be because of the specificity of the study area and the econometric method. The model shows that the population, manufacturing value added, the colonial link as well as the geographic proximity is significant and expected signs. While the business climate, the difference in GDP per capita between countries, the distance between the capitals and financial inflows appear as constraints for exports manufacturing. These results show that CEMAC remains fragile to be eligible for strong manufacturing and rapid industrialization. For this reason, they must create a more dynamic cooperation between the countries of the zone.

\section{Acknowledgments}

We thank the anonymous referees for their comments and suggestions. In addition, we thank Dontsi, Avom D. who kindly read the early versions of this article. However, the authors remain entirely responsible for errors and shortcomings that may remain in the text.

\section{References}

Agbodji Akoete, E. (2007). Intégration et échanges commerciaux intra sous régionaux: le cas de l'UEMOA. Revue Africaine de l'intégration, I(1), 161-188.

Anderson, J.E., \& Van, Wincoop. (2003). Gravity with gravitas: a solution to the border puzzle. American Economic Review, 93(1), 170-192. https://doi.org/10.1257/000282803321455214

Anderson, J.E. (1979). A Theoretical Foundation for the Gravity Equation. American Economic Review, 69(1), 106-116.

Anderson, J.E., \& Yotov, Y.V. (2010). The changing incidence of geography. The American Economic Review, 100(5), 2157-2186. https://doi.org/10.1257/aer.100.5.2157

Avom, D., \& Mignamissi, D. (2013). Evaluation et analyse du potentiel commercial dans la Communauté Economique et Monétaire de l'Afrique Centrale (CEMAC). L'actualité économique, revue d'analyse économique, 89(2), 115-145. https://doi.org/10.7202/1024887ar

Avom, D. (2005). Les déterminants des échanges dans la CEMAC: une investigation empirique. Economie Appliquée, 58(2), 127-153.

Baier, S.L., \& Bergstrand, J.H. (2001). The growth of world trade: tariffs, transport costs, and income similarity. Journal of International Economic, 53(1), 1-27. https://doi.org/10.1016/S0022-1996(00)00060-X

Bensafta, K.M. (2014). Les exportations des produits manufacturiers et convergence du niveau de vie: cas d'un pays exportateur de pétrole, HAL, archives-ouvertes, Document de recherche, n²013-06.

Bergstrand, J.H. (1985). The Gravity Equation in International Trade: Some Microeconomic Foundations and Empirical Evidence. The Review of Economics and Statistics, 67, 474-481. https://doi.org/10.2307/1925976

Carrère, C. (2004). African Regional Agreements: their impact on trade with or without currency Unions. Journal of African Economies, 13(2), 199-239. https://doi.org/10.1093/jae/ejh010

Courlet, C. (1988). L'analyse de l'industrialisation du tiers monde: acquis théoriques et modalités d'une remise en cause. Revue Tiers Monde, 29(119), 639-664. https://doi.org/10.3406/tiers.1988.3712

De Melo, J. \& Grether. (1997). Commerce International, théories et applications. De Boeck Université.

Deardorff, A.V. (1998). Determinants of bilateral trade: does gravity work in a neoclassical world? In The regionalization of the world economy (7-32). University of Chicago Press. https://doi.org/10.7208/chicago/9780226260228.003.0002 
Evenett, J.S., \& Keller, W. (2002). On Theories Explaining the Success of the Gravity Equation. Journal of Political Economy, 110(2), 281-316. https://doi.org/10.1086/338746

Gbetnkom, D., \& Avom, D. (2005). Intégration par le marché: le cas de l'UEMOA. Région et développement, 22, 86-103.

Guillaumont, P. (1978). Substitution des contraintes dans le financement international du développement. Revue économique, 1057-1090. https://doi.org/10.3406/reco.1978.408434

Hausman, J.A., \& Taylor, E. (1981). Panel data and unobservable individual effects. Econometrica, 49(46), 1377-1398. https://doi.org/10.2307/1911406

Havrylyshyn, O., \& Pritchett, L. (1991). European trade partners after the transition. Working Papers, $\mathrm{n}^{\circ} 748$, The world Bank.

Hinitch, A.Y., D’Aveni, R.A., \& Lewin, A.Y. (1996). New organizational forms and strategies for managing in hypercompetitive environments. Revue Organization Science, 7(3), 251-301. https://doi.org/10.1287/orsc.7.3.211

Laporte, B. (1998). Contraintes structurelles, politiques nationale et coopération régionale: déterminants des échanges entre les pays d'Afrique de l'Ouest?. Revue Canadienne d'Etudes du Développement, 19(1), 451-479. https://doi.org/10.1080/02255189.1998.9669739

Linneman, H. (1966). An Econometric Study of International Trade Flows. Amsterdam, North-Holland.

Luo, X. (2001). La mesure de la distance dans le modèle de gravité: une application au commerce des provinces chinoises avec le Japon. Régions et Développement, 13, 163-180.

Norro, M. (1998). L'Afrique subsaharienne: de la crise à une croissance durable, in Banque Mondiale, 19.

Novy, D. (2012). International Trade without CES: Estimating Translog Gravity. No 9125, CEPR Discussion Papers. Retrieved from http://EconPapers.repec.org/RePEc:cpr:ceprdp:9125

Ocampo, J.A. (2005). Beyond reforms: structural dynamics and macroeconomic vulnerability. Stanford University Press. https://doi.org/10.1596/978-0-8213-5819-7

OMC. (2002). Influence de la taille d'un pays sur son économie et son commerce extérieur. Document WT/L/447.

Ominami, C. (1986). Le tiers monde dans la crise, édition la découverte.

Pöyhönen, P. (1963). A Tentative Model for the Flow Trade between Countries, Weltwirtschaftliches Archiv. Band 90, heft 1.

Rajan, R.G., \& Zingales, L. (1998). The governance of the new entreprise. CSRP, working papers, $\mathrm{n}^{\circ} 487$.

Rose, A. (2000). One money, one market: estimating the effect of common currencies on trade. Economic Policy, 15(30), 8-45. https://doi.org/10.1111/1468-0327.00056

Schumpeter, J.A. (1950). Capitalism, socialism and democracy (3rd ed.). Harper and Row.

Szirmai, A. (2012). Industrialization as an engine of growth in developing countries, 1950-2005. Structural Change and Economic Dynamics, 23(4), 406-420. https://doi.org/10.1016/j.strueco.2011.01.005

Tinbergen, J. (1962). Shaping the World Economy, Suggestions for an International Economic Policy. The Twentieth Century Fund, New York.

United Nations. (2014). Rapport sur l'amélioration du climat des affaires en Afrique Centrale, CEA, BSAR.

Van de Ven, A.H. (2005). Running in packs to develop knowledge-intensive technologies. Mis Quarterly, 29(2), 365-378. https://doi.org/10.2307/25148683

Zugravu, N. (2009). Trade and Sustainable Development: Should "transition countries" open their markets to environmental goods? Université Paris-I Panthéon Sorbonne, p.34.

\section{Note}

Note 1. Foreign Direct Investments (FDI); Portfolio Investments (PI) ; Public Aid for Development (PAD) ; Transfer of Migrants (TM). 